\title{
THE DEVELOPMENT OF TOURISM BASED ON LOCAL ECONOMIC IN PUJON KIDUL VILLAGE
}

\author{
Kaewketsaya Songthan $^{1^{\star}}$, Nuttapol Lertsirisakulchai ${ }^{2}$, Pannipa Muangmontre ${ }^{3}$, \\ Atika Dwi Febriyanti ${ }^{4}$, Achmad Apriyanto Romadhon ${ }^{5^{*}}$ \\ 1.2.3 Bachelor of Public Administration (Fiscal Management) \\ College of Local Administration, Khon Kaen University, Thailand \\ ${ }^{4}$ Bachelor of Government Science, Faculty of Social and Political Science, \\ University of Muhammadiyah Malang, Indonesia \\ ${ }^{5}$ Government Science Faculty of Social and Political Science, \\ University of Muhammadiyah Malang, Indonesia \\ Email: ${ }^{1}$ kaewketsaya_s@kkumail.com \\ Email: ${ }^{2}$ nuttapol_k@kkumail.com \\ Email: ${ }^{3}$ pannipa.m@kkumail.com \\ Email: ${ }^{4}$ atikadwifebriyanti@gmail.com \\ Email: ${ }^{5}$ achapriyantoromadhan@gmail.com
}

\begin{abstract}
The development of Tourism based on the local economy is significant. Also, in many regions with unique physical characteristics and rich in natural resources, it can be further developed to be a popular tourist destination. Moreover, it can stimulate the local economy, such as together. The purpose of this research is to find the development of tourism based on the local economy in Pujon Kidul village and find any problems and obstacles in the local economic development of the local government, including the community's well-being. The main problem that may deter development is human resources from the community because of most people in the community. There is still relatively little participation in community activities, including the interest in development. This study's research method is a qualitative research method, including secondary data and data collected from interviews. There is a descriptive description. Tourism development is based on the local economy with an emphasis on management in two principles. It covers agriculture and animal husbandry; from the results of this study, it can be concluded that an essential step in the development of local economy-based tourism is the territorial diagnosis and institutional mapping, the process of growing sensitivity, and creating a local forum I regionally. The implementation of these three steps can be said to have been successfully implemented in Pujon Kidul village. Therefore, the study concludes that local economic development and the identification of obstacles to self-government. It includes what can be resolved quickly, make tourism development more efficient, and lead to the fact that local people Can make money To the community for a better quality of life and well-being.
\end{abstract}

Keywords: Create a local, Economic Development Growing Sensitivity, Local Territorial diagnosis 


\section{INTRODUCTION}

Pujon Kidul is a village in Pujon Subdistrict, Malang Regency, East Java Province, having a land area of $27 \mathrm{~km} 2$. In Pujon Kidul village, there are three hamlets, namely Maron, Tulungrejo, and Krajan. Pujon Kidul village's total population is around \pm 4,121 inhabitants, with a population density of 200. Pujon Kidul Village is one of the tourist destinations in East Java, having unspoiled tourism potential suitable for refreshing and educational tourism. Activities are undertaken in educational tours such as picking vegetables, animal husbandry, studying alternative energy, milk processing, and Outbound / Fun Games. Pujon Kidul Village has a variety of traditional arts that can be enjoyed by tourists, namely the art of Kuda Lumping, Pencak Silat, and Sanduk Dance. Pujon Kidul village also has unique culinary and souvenirs offered to tourists, such as outstanding food, dairy products, handicrafts, and agro products that can be enjoyed together with their respective families (Kota Batu, 2020). ${ }^{1}$

The area of Pujon Kidul village, in general, is very suitable for agricultural and plantation land because of its geological characteristics in the form of black soil, which is classified as fertile land. Based on Pujon Kidul Village data, some suitable plants are corn, fruits such as apples, tomatoes, and carrots. The economic situation is closely related to the source of people's livelihood and as the heart of human life. Everyone is always trying to get a job following their respective fields and everyday life. Of the total population of 4,146 people, with a total workforce of 1,875 people, the economic activities of the Pujon Kidul village are still dominated by the agricultural sector and animal husbandry, given that the area of the village of Pujon Kidul is $65 \%$ of the rice fields which are the land for community livelihoods. The daily life of the Pujon Kidul village community is farming, farming, agricultural labor, and raising livestock (cows, goats, chickens, ducks), fisheries, buildings, construction workers, and trade and others. In contrast, the local economic potential is owned by Pujon Kidul, namely agriculture, plantations, springs, and livestock. Pujon Kidul village has a large agricultural land that can be used as an opportunity for the community to use it. Potential as a source of the economic community. However, some people also work as Civil Servants, private employees, tailors, and so on (Pujonki Tourism Village, 2017). ${ }^{2}$

Tourism development has also been developed in Maron Hamlet, Pujon Kidul Village, by developing competitiveness against other tourism objects for community empowerment both internally and universally. Coban Rondo Nature Tourism is the tourism

1 Kota Batu. "Portal Pesmi Pemerintah Kota Batu." Retrieved from https://www.batukota.go.id/. January 2020.

2 Desa Wisata Pujonki. “An electronic information system for Pujon Kidul village.” 2017. Retrieved from https:// www.sie.pujonkidul.desa.id/. January 2020. 
object that the people of Pujon Kidul Village can offer to the eyes of the world community, especially in Maron Hamlet. It depicts the beauty of the water flow accompanied by the birdsong. It welcomes tourists, and the tourist can also enjoy the beauty of the Mountains. It can hypnotize the power of people's views from the density of work every day. Educational Tourism, with various methods, opens up our discourse about the importance of preserving this nature.

This activity is an effort to realize the development program of Pujon Kidul Tourism Village (Maron sub-village) as a center and pilot of the Tourism Village in Pujon Kidul. This step was taken to improve the community's economy in the future (Hastuti, 2013) ${ }^{3}$ However, it is used explicitly as a Home Stay to serve tourists. Discussion about tourism, including the Tourism Village, is related to many things that will be sold to tourists. It can be produced for tourism service providers and the general public. It is because there will be various things that can be sold to tourists, such as culture or regional arts, traditional food and drinks, and handicrafts as souvenirs. It sells nature's beauty and uniqueness (Wibowo, 2010). ${ }^{4}$ However, as a key to developing rural tourism and tourism, most important is the willingness and readiness of the community to accept and welcome tourists openly and start trying to practice the concept of the Tourism Village itself. Furthermore, all society components must support the development and serve with a neat and clean appearance for tourists. ${ }^{5}$

\section{REVIEW OF LITERATURE}

Research on the development of tourism based on the local economy, actually those who have done it, such as research conducted by Septiofera, Djambur, Arika (2016), using qualitative descriptive methods and data collection through interviews. Moreover, the analysis in their research focuses on how community participation with tourism development in the village of Pujon Kidul. The researchers then concluded that the division of society in the development of tourist villages in Pujon Kidul was still relatively low. Several inhibiting factors include low motivation, low Human Resources, and many who experience difficulties in politics and regulations to license exceptional food manufacturing. However, there are still supporting factors that can enhance the development of this tourism. the village, which still has adequate care and communication between people. ${ }^{6}$

3 Hastuti, S. Purwantara and K. Nurul, "Model Pengembangan Desa Wisata Berbasis Kearifan Lokal Sebagai Strategi Pengentasan Kemiskinan di Lereng Merapi Kabupaten Sleman Daerah Istimewa Yogyakarta," Universitas Negeri Yogyakarta. 2013.

4 A. A. Wibowo, "Pengembangan Desa Wisata Sebagai Model Pemberdayaan Masyarakat di Desa Brayut, Kecamatan Sleman, Kabupaten Sleman, Provinsi Daerah Istimewa Yogyakarta," Universitas Sebelas Maret. 2010.

5 As stated in E. Kastenholz and J. Lima," work entitled The integral rural tourism experience from the tourist's point of view - A qualitative analysis of its nature and meaning," Tour. Manag. Stud. vol. 7, 2011. 62-74.

6 Septiofera, Djambur, Arika. "Analysis of community participation in the development of tourist village (study in Pujon Kidul village, pujon district, Malang district)." 2016. Retrieved from http://administrasibisnis. studentjournal.ub.ac.id/index.php/jab/article/view/1296/1630. January 2020. 
The study was conducted by Christian Rimbun (2018), who used descriptive qualitative research, data collection by observation, interviews, and documentation. Moreover, data analysis uses an interactive data analysis model. His research technique focuses on how tourism promotion activities in paddy cafe. Paddy cafe is one of the tourist destinations in the village of Pujon Kidul. According to them, where they get the final result, promotional activities in Pujon Kidul are still not optimal when seen from the effectiveness of promotional tools and media used. The difference between this research and the above research converges on the problem of local economic development. How can it be seen that Pujon Kidul is one village that can wisely utilize the natural resources in its village, the village government, and its people can turn it into something that can produce coffers? rupiah coin purse, which will automatically improve the economy in the village. ${ }^{7}$

\section{Theory Martin Gasser,Carmela Salzano,Roberto Di Meglio And Alfredo Lazarte-Hoyle ${ }^{8}$}

Local Economic Development encourages local ownership of development activities through a process of participation, information exchange, coordination of initiatives, and investment of time and resources by local stakeholders. Local Economic Development interventions are based on specific necessary steps, including:

\section{Territorial Diagnosis and Institutional Mapping}

The purpose of territorial diagnosis is to gather information about an area and its resources to understand local conditions. The implementation of institutional mapping focused on the existence, objectives, and activities of local stakeholders and their dynamics. Some short-term economic development activities are funded by bilateral donors and the United Nations, NGOs, and social mobilization (cooperatives, communitybased organizations). Relevance and benefits Territorial diagnosis \& Institutional Mapping have become increasingly clear through several local economic development stages. It is because the information collected provides the basis for immediately undertaking activities that have an immediate impact, as well as those activities that have more socially and environmentally sustainable impacts for the medium term and long term. However, data collection needs to be done continuously, because of changes in circumstances and changes in the scale of development and new actors who are more influential in the area.

7 Christian Rimbun. "Analysis of tourism promotion activities in cafe sawah village tourism Pujon Kidul." 2018. Retrieved from http://administrasibisnis.studentjournal.ub.ac.id/index.php/jab/article/view/ 1296/1630. January 2020.

8 Martin Gasser,Carmela Salzano,Roberto Di melgio, Alfredo Lazarte Hoyle, "Pembangunan Ekonomi Lokal Dalam Masa Krisis", 


\section{The process of growing sensitivity}

At this stage, it involves efforts to increase the awareness of stakeholders about how much their actions can influence other actors, what adjustments need to be made, and how closely the existing synergies can help the achievement of shared development goals. The main objective of this phase is to increase public awareness and understanding of issues affecting socio-economic development in the region and foster a sense of belonging to the Local Economic Development process. It is hoped that dialogue will be held between key stakeholders on economic issues and significant public policies that can produce solutions to common problems and opportunities. This effort is expected to produce crystallization of vision for economic recovery and setting priorities for investment and target groups. Another significant hope of this phase is that local stakeholders can slowly have this development process.

\section{Create a local/regional forum}

Creating a local/regional forum is a continuation of the consensus development process. The lack of dialogue forums where individuals and businesses can express their needs can cause great tension and neglect of social problems. A forum that houses several influential figures who have diverse expertise in managing regions will facilitate efforts to identify vulnerable areas, share knowledge and skills at all levels, and convey information among all partners involved in the development process. Thus the forum is expected to regulate preparing a coordinated action plan, which includes efforts to improve technical and managerial expertise in the public and private sectors and essential elements needed to carry out recovery efforts that are socially and environmentally sustainable.

\section{RESEARCH METHODS}

Research in this study includes data analysis methods in the discussion process, including collecting data sources for data collection to be accurate and accurate. However, the participation of people in the community may affect the development of obstacles. If the local government still does not have a suitable management method. Specifically, this research seeks to answer leaders governing development. Includes effective methods for overcoming and solving problems, and researchers have the following methods in conducting research.

1. Key Informants

2. Research Instruments

3. Data sources and data collection

4. Data analysis

\section{Key informants}

The primary informants were the Village Chief of Pujon Kidul Kitul and the owner of dairy products.

\section{Research Instruments}

The study was conducted in the Pujon Kidul Tourism Village in East Java 
Province, Malang Regency, using qualitative research. The model describes primary data obtained from observations and interviews that provide data based on data collection. This model illustrates secondary data derived from studies of research papers in journals and online media. Including resources from Malang Regency to bring data into decision support and be more comprehensive. Interview methods used in this study were characterized as semi-structured interviews (semi-structured or guided interviews), byline interviews (Interview Guidelines) conducted in the form of in-depth interviews using in-depth interviews, interviews with informants

The observer will participate in the observation. The research, commissioned by a team who knows this area, informs about the problem and provides useful information about this research. The instruments used in this study are as follows

\section{a. Researchers}

Researchers are essential tools for observers, asking questions, recording, and analyzing data. However, because in-depth interviews are communication or conversation to collect factual data and opinions, interview questions can change. According to the situation or information received

\section{b. Interview}

Researchers used semi-structured interviews. (Semi-Structured Interview), before the interview, researchers will get to know to build relationships and familiarity with the primary data providers. After that, we conduct in-depth interviews, namely informal interviews, to find information and answer key informant questions.

\section{c. Interview equipment}

Researchers use various tools, such as voice recorders, to update audio data in conversations and interviews with the primary data providers. The latter advocate before each recording and interview recording form, including notepad. (Fields-Note) for researchers to use information obtained from interviews, gathering, including opinion matters.

\section{Data sources and data collected}

Researchers data from various data sources. From books, journals, research, theses, and web sites to study and discuss choosing to attract interesting problems Where researchers classify data according to the collection of collecting data into two types as follows

\section{a. Primary data}

Primary data is data in the form of individual experiences. Data collection is done through in-depth interviews with key informants, where purposive sampling is used to select a particular sample, the village head. This research has the following data collection process

Step 1: Plan an in-depth interview and organize the data collection process, starting with the recruitment and selection of key informants, preparation, and questions to be interviewed with key informants. 
Step 2: Recruitment and selection of key informants. The researcher selects the main informant, the village head. And product owners by selecting critical informants based on qualifications that meet the needs of researchers in receiving in-depth information

Step 3: Meet alone and introduce objective informants. Before the researcher meets the main informant, the researcher has called in the initial information to get to know and build an excellent relationship to gain trust. Furthermore, ready to provide complete information and then make an appointment, date, time, and convenient location for the main informant. Statistics are officially introduced, and the goals are clear again before the next interview.

Step 4: In-depth interviews with key informants Before the interview, researchers prepare and interview questions by looking for information related to the Pujon Kidul village and village tourism development. Before starting the interview, the researcher asked permission to use a voice recorder and record data simultaneously. Interviews are friendly, not pressure, to create peace and inconvenience in providing information and answering questions such as friends, relatives, conversations, etc. At the end of the interview, the researcher asks permission to request additional information over the telephone if the information received is insufficient for analysis and conclusions research.

Step 5: Gather data from interviews by researchers starting from the main informant's transcript or transcript and making individual documents. Then, the researchers read the document obtained from the transcript. Along with reading information obtained from journaling to find the information useful for research and gathering useful information from each person for further analysis and research summary

Step 6: Data analysis and conclusions from interviews with researchers use the method of data classification (Tyrwological Analysis) and keyword analysis (Domain Analysis). The researchers take data to consider the main problem and then divide it into smaller problems. Afterward, the researchers make an inductive summary (Analytic Induction) to summarize data that will be linked to data obtained from theoretical studies or literature reviews to obtain information that can answer research questions and research objectives.

\section{b. Secondary data}

Secondary data is data obtained from research from books, newspapers, magazines, articles, academic documents, web sites, and related research

\section{Data analysis Researchers}

Data analysis Researchers will use information obtained from in-depth interviews to collect data and analyze qualitatively by using that information to separate the problems needed to make clear and accurate boundaries. Then take information from the interview to write down the interview 
verbatim and read the interview repeatedly to consider the information received. Moreover, use typological analysis to classify with keyword analysis (Domain Analysis) by classifying related words into the same data set and then analyzing it as the main points and sub-points. Then, use the information to conclude by writing the relationship between the main points and small issues. To use the information to interpret according to the research objectives. To link to the concepts and theories of this research and summarize the data descriptively.

\section{DISCUSSION}

About Pujon Kidul Village:

Pujon Kidul is a small village located in Malang district, East Java Province. This village is located about $29 \mathrm{KM}$ from downtown Malang. After the election of Rudi Hartoko as the village head in 2011. in his first nomination as village head, he had the mission of "utilizing the natural potential to become a tourist village area." Furthermore, sure enough, after Rudi Hartoko was elected as the village head, Pujon Kidul Village was transformed into a tourist village that was quite busy until now. There are two main focuses of the Pujon Kidul village, namely agriculture and animal husbandry.
Nevertheless, in Pujon Kidul village, there is also a cultural village where this cultural village established a studio called "Sanggar Putra Garuda." However, this cultural village tour is still in the planning stage and is awaiting its inauguration. Since Rudi Hartoko leads Pujon Kidul Village, Pujon Kidul Village has gradually become a village with good development in all aspects. By utilizing local economic development, Pujon Kidul can prove an extraordinary success for his village. It is proven that Pujon Kidul has increased significantly, like the table 1 .

From the table 1, it can be seen that before forming a village fund, receiving 20-30 million rupiahs. After the village head formed a village fund (BUMDes), the village saw an increase of 162 million in 2017 and 1 billion rupiahs in 2018, considered an increase in income fast. In the village of Pujon-Kidul, it has a turnover of around 15 billion rupiahs per year. Visitors in the village of PujonKidul are usually around 700 people per day, and on weekends - more than 2,000 people. Only by relying on the local economy, Pujon Kidul can prove its success. Local economic development has several essential indicators. Here are some essential steps that can affect local economic development:

Table 1. Income from BUMDes fund establishment

\begin{tabular}{|c|c|c|c|}
\hline \multirow{3}{*}{ Income } & \multirow{2}{*}{$\begin{array}{l}\text { Before establishing } \\
\text { a fund }\end{array}$} & \multicolumn{2}{|c|}{ After establishing a fund } \\
\hline & & 2017 & 2018 \\
\hline & Rp.20-30 million & Rp.162 million & Rp. 1 billion more \\
\hline
\end{tabular}




\section{Territorial diagnosis and institutional mapping}

This territorial diagnosis was made by the village head, who was the first person to have the idea of making Pujon Kidul village a private area. He had collected information in Pujon Kidul village, and he had observed all the resources there and understood the area. Where in the village, Pujon Kidul currently has two focus, namely agriculture and animal husbandry. At present, both of them are the primary commodities of Pujon Kidul Tourism Village. As for institutional mapping, several institutions have contributed to the development of Pujon Kidul tourism villages. According to some villagers, youth organizations have a significant role in developing tourist villages. They are young people who have a high awareness of tourism villages.

\section{The Process of Growing Sensitivity}

This process of growing sensitivity is a phase where village officials play quite a lot here. In the village of Pujon, Kidul village officials and youth youths plunge directly into the community to foster the sensitivity of the community of Pujon Kidul village to the tourist village. The government also conducts socialization and learning about village tourism to the community. Nevertheless, in this process, the village officials were quite overwhelmed because many villagers were less concerned with the existence of a tourist village.

\section{Promote Local / Regional Forums}

In the field of promotion, the people of Pujon Kidul village do not have a specific strategy, at first the promotion of the Pujon Kidul tourism village only through the internet and social media. However, when many television stations cover the Pujon Kidul tourism village, with their coverage being broadcasted indirectly, this could be indirectly promising free promotional event.

\section{CONCLUSION}

From the research, it can be concluded that the development of tourism is based on the local economy in Pujon Kidul village. The village emphasizes the management of two critical principles: agriculture and animal husbandry, including the village's culture and traditions.

Based on the discussion above, to develop a tourism village based on the local economy, there must be strong cooperation between village officials and their citizens. Without strong cooperation, anything will never achieve its success.

Furthermore, some essential steps in the development of tourism based on the local economy can be summarized as follows:

\section{Territorial diagnosis and institutional mapping}

The territorial diagnosis has been made very well by the village head of Pujon Kidul as the originator of a tourism village; the diagnosis has been carried out on target. 
Now the Pujon Kidul can achieve success. As for institutional mapping, several institutions such as the private sector and SMEs have to contribute to the development of the Pujon Kidul tourism village.

\section{The Process of Growing Sensitivity}

Pujon Kidul village officials have been quite successful in growing the village communities' sensitivity until now, villagers have begun to care about a tourist village's existence. Although some residents remain apathetic about the village tourism, the village officials still need to do more in-depth socialization to the people of Pujon Kidul village.

\section{Promote Local / Regional Forums}

The promotion of rural tourism in Pujon Kidul is mostly done through the internet and social media, inviting influencers at a large event held in Pujon Kidul village to promote Pujon Kidul village to the outside community.

However, the government must be able to revitalize local culture and change communities/residents' participation in communities, especially tourism villages. Culture, rehabilitation, and the importance of real estate services while showing their potential will help community tourism development, such as village mapping, as a useful tool for studying and solving problems in Village development.

\section{REFERENCES}

A. Wibowo, "Pengembangan Desa Wisata Sebagai Model Pemberdayaan Masyarakat di Desa Brayut, Kecamatan Sleman, Kabupaten Sleman, Provinsi Daerah Istimewa Yogyakarta," Universitas Sebelas Maret. 2010.

Christian Rimbun. "Analysis of tourism promotion activities in cafe sawah village tourism pujonkidul “ .2018.Retrieved from http://administrasibisnis. studentjournal.ub.ac.id/index.php/ jab/article/view/ 1296/1630. January 2020.

Desa Wisata Pujonki. "An electronic information system for Pujon Kidul village." 2017. Retrieved from https:// www.sie.pujonkidul.desa.id/. January 2020.

E. Kastenholz and J. Lima, "The integral rural tourism experience from the tourist's point of view - A qualitative analysis of its nature and meaning," Tour. Manag. Stud. vol. 7, 2011. 62-74.

Hastuti, S. Purwantara and K. Nurul, "Model Pengembangan Desa Wisata Berbasis Kearifan Lokal Sebagai Strategi Pengentasan Kemiskinan di Lereng Merapi Kabupaten Sleman Daerah Istimewa Yogyakarta," Universitas Negeri Yogyakarta. 2013. NIDN0027066206

Martin Gasser,Carmela Salzano,Roberto

Di melgio, Alfredo Lazarte Hoyle, "Pembangunan Ekonomi Lokal Dalam 
Masa Krisis", Kota Batu. "Portal Pesmi

Pemerintah Kota Batu.” Retrieved from

https://www.batukota.go.id/. January 2020.

Netralnews. Village Funds Significantly Boost Real Revenues of Pujon Kidul Village. Retrieved fromhttps://en.netralnews. com/news / business / read/26772/ village.funds.significantly.boost.real. re venues.of.pujon.kidul.village. March 2020.

Septiofera, Djambur, Arika. "Analysis of community participation in the development of tourist village (study in pujonkidul village, Pujon District, Malang district).” 2016. Retrieved from http://administrasibisnis. studentjournal.ub.ac.id/index.php/ jab/article/view/1296/1630. January 2020

Yothin Sawangdee. "Qualitative Research." Mahidol University. Retrieved from https://www.rlc.nrct.go.th/ ewt_dl.php?nid=1079. March 2020. 